\title{
INTERTEKSTUALITAS BERITA-BERITA UTAMA INTERNASIONAL PADA SURAT KABAR DI TIMUR TENGAH
}

\author{
Muhammad Kamal Bin Abdul Hakim* \\ *Dosen Program Studi Pendidikan Bahasa Arab \\ Fakultas Bahasa dan Seni Universitas Negeri Jakarta \\ Kampus A, Jl. Rawamangun Muka Jakarta 13220 \\ Email :m.kamal.hakim@gmail.com
}

\section{الملخص}

يهدف هذا البحث إلى تحديد تناص عناوين الأخبار الرئيسية الدولية في صحيفة الشرق الأوسط السعودية و صحيفة الأهرام المصرية ، وإيجاد التماسك و الاتساق بين نصوص أخبارهما . ويستخدم هذا البحث طريقة تحليل المحتوى هو العثور على تناقص العناوين الرئيسية الدولية في الصحيفتين من خلال التماسك والاتساق من نصوصهما. وخلص البحث أن ترابط العناوين الدولية في صحيفة والشرق الأوسط والأهرام في موضوع داعش (دولة إسلامياة في الشام والعراق) والتماسك الذي تم الحصيول عليه في صحيفة الشـرق الأوسط هو استبدال النص 3 شواهد ، وقطع النص 2 شاهدان ، و تكرار النص 3 شـواهد. وأما في صحيفة الأهرام فلم يوجد استبدال النص وقطع النص ، و تكرار النص 7 شواهد .ويوجد الاتساق في صحيفة والشرق الأوسط من ناحية اقتراح النص9 شواهد وافتراض النص 9 شواهد. كما يوجد في صحيفة الأهرام من ناحية اقتراح النص9 9 شواهد وافتراض النص 9 شواهد. كلمات البحث: الصحف، العناوين الرئيسية، التماسك، الاتساق 


\begin{abstract}
ABSTRAK
Penelitian ini bertujuan untuk mengetahui intertekstualitas berita-berita utama internasional pada surat kabar As-Sharq Al- Awsat Saudi Arabiah dan surat kabar Al-Ahram Mesir, dan menemukan kohesi dan koherensi pada keduanya. Penelitian ini menggunakan metode analisis isi yaitu menemukan intertekstual berita-berita utama internasional pada kedua surat kabar melalui kohesi dan koherensi. Penelitian ini menyimpulkan ada keterkaitkan berita-berita utama internasional pada surat kabar As-Syarqul Awsat dan Al-Ahram pada tema ISIS. Kohesi didapatkan pada surat kabar Syarqul Awsat yaitu: subtitusi 3 teks, elipsis 2 teks, dan pada Rekuren 3 teks. Pada surat kabar Ahram tidak ditemukan subtitusi, elipsis, dan rekuren didapatkan 7 teks. Koherensi didapatkan pada surat kabar Syarqul Awsat proposisi 9 teks dan presuposisi 9 teks sedangkan pada surat kabar Ahram didapatkan proposisi 9 teks dan presuposisi 9 teks.
\end{abstract}

Kata kunci : surat kabar, berita utama, intertekstual, kohesi, koherensi 


\section{PENDAHULUAN}

Penelitian ini akan mengungkapkan intertekstualiatas berita-berita utama internasional pada surat kabar di Timur Tengah. Surat kabar online yang terbit di Timur Tengah sangat banyak, maka akan difokuskan pada As-Sharq Awsat yang diterbitkan di Saudi Arabiah dan Al-Ahram yang diterbitkan di Mesir. Kedua surat kabar ini cukup mewakili surat kabar di Timur Tengah karena Saudi Arabiah merupakan negeri sumber bahasa Arab yang terletak di Asia dan Mesir merupakan pusat peradaban Arab di benua Afrika.

Sebelum membicarakan intertektualitas berita pada kedua surat kabar tersebut, penulis menguraikan terlebih dahulu hal-hal yang terkait dengan intertektualitas berita utama internasional pada surat kabar As-Sharq Awsat dan Al-Ahram yaitu: apakah intertekstualitas, kohesi dan korehensi itu? apakah surat kabar dan berita utama itu? bagaimanakah keterkaitan berita utama internasional pada surat kabar As-Sharq Awsat dan Al-Ahram? bagaimanakah bentuk kohesi dan koherensi berita utama pada kedua surat kabar tersebut?

Surat kabar memiliki peran yang sangat besar dalam penyebaran informasi kepada masyarakat. Keberadaan surat kabar memberikan kontribusi besar dalam penyampaian informasi dan berita dari belahan dunia ke belahan dunia yang lain.

Di era digital ini surat kabar telah mengalami perkembangan yang sangat pesat. Media yang digunakan dalam surat kabar tidak lagi bertumpu pada media cetak dengan menggunakan kertas sebagaimana awal perkembangannya. Saat ini banyak surat kabar yang telah menyediakan fasilitas berita online yang dapat diakses oleh semua orang di seluruh dunia.

Di antara surat kabar di Timur Tengah yang menyediakan fasilitas berita online berbahasa Arab adalah As-Sharq Awsat yang diterbitkan di Saudi Arabiah dan Al-Ahram yang diterbitkan di Mesir.

Berita-berita yang disampaikan pada kedua surat kabar tersebut khususnya berita internasional menyajikan berita-berita terhangat di belahan dunia terutama dari negera-negara tetangga di kawasan Timur Tengah. Terdapat beberapa kesamaan dalam isi berita pada satu surat kabar yang diterbitkan pada tanggal yang berbeda baik dari bentuk makna dan struktur yang digunakan.

Bahasa yang digunakan dan bagaimana struktur pada surat kabar, semuanya bergantung pada konteksnya. Komunikatif atau tidaknya sebuah berita, serta tekstual atau tidaknya berkaitan dengan intertekstualitas, yaitu mengenai keadaan yang terkait dengan faktor-faktor yang menyebabkan ketergantungan pemanfaatan suatu teks terhadap pengetahuan mengenai satu teks yang dijumpai sebelumnya, atau sesudahnya. Dalam pemakaian kalimat, serangkaian kalimat memiliki keterkaitan baik dalam wujud ataupun maknanya dengan serangkaian kalimat yang lain. Sebagai contoh, ada keterkaitan makna dan struktur antara berita-berita yang disajikan pada surat kabar yang sama pada tanggal yang berbeda.

Berdasarkan hal-hal tersebut di atas, penulis tertarik mengkaji intertekstualitas berita-berita internasional pada surat kabar As-Sharq Al-Awsat yang diterbitkan di Saudi Arabiah dan surat kabar Al-Ahram yang diterbitkan di Mesir terkait gejolak yang terjadi di beberapa negera Timur Tengah . Kedua surat kabar ini cukup mewakili Timur Tengah ditinjau dari geografi dan kedudukan negara dimana kedua surat kabar ini diterbitkan. Isi berita yang disajikan juga dapat dimanfaatkan untuk pembelajaran bahasa Arab. Dalam hal ini untuk meningkatkan pengunaan gramatikal bahasa Arab di dalam teks dan penggunaan bahasa arab pers di dalam kemahiran berbahasa Arab.

\subsection{Pengertian Intertekstualitas}

Intertektual berasal dari kata Intertextuality atau intertexto yang berarti bercampur sambil merajut". Intertextuality merupakan istilah yang pertama kali diperkenalkan oleh Julia Kristeva. Ia mengatakan bahwa, istilah intertekstual pada umumnya dipahami sebagai hubungan suatu 
teks dengan teks lain. Selanjutnya dikatakan,tiap teks merupakan penyerapan dari teks-teks lain.(Kristeva,1980:69).

Tidak seperti Kristeva, Genett tidak mempertimbangkan referensi dari teks yang lain menjadi sifat umum dan literatur; namun sebaliknya ia melihat karakteristik dari beberapa teks tertentu. Ia menyebut kualitas umum hipertekstual ini dibedakan ke dalam lima tipe yaitu (Genette 1997a: 5):

- Istilah intertektualitas menunjukkan kehadiran efektif sebuah teks A didalam teks B, contohnya dalam bentuk kutipan atau kiasan

- Parateks merupakan bagian dari sastra yang dikelompokkan ke dalam teks yang tepat, seperti judul, catatan, kata pengantar, motto, dll.

- Fenomena metatekstual akan lebih familiar pada sesuatu yang klasik, dimana teks B mengomentari teks A

- Arsitekstual merujuk kepada fakta bahwa teks-teks tersebut termasuk ke dalam jenis sastra yang berbeda dan menunjukkan hubungan teks ke dalam aturan jenis.

- Hipertekstual sebagai pengambilan text B (the hiperteks) dari teks A (the hippoteks) tanpa menjadikan teks B sebagai komentar atas teks A

Dari pendapat Genett dapat dipahami bahwa istilah intertekstual adalah terjadinya kesinambungan dan keterkaitan pada satu teks dari teks sebelumnya. Ini dapat dilihat dari kutipan dari teks sebelumnya ataupun kiasan yang menggambarkan teks sebelumnya.

Sedangkan menurut Beaugrande istilah intertekstual berkaitan dengan caracara bagaimana proses produksi dan resepsi pada teks tertentu tergantung kepada pengetahuan partisipan terhadap teks-teks yang lain (Beaugrande,1981:182).

Intertekstualitas

mencakup

keterkaitan faktor-faktor yang menyebabkan ketergantungan pemanfaatan suatu teks terhadap pengetahuan sebelumnya. Intertekstualitas dapat menghubungkan rangkaian kalimat yang memiliki keterkaitan dengan rangkaian kalimat yang lain, sebuah bab dengan bab lain dalam sebuah buku, atau bahkan sebuah buku dengan buku lain yang diikat oleh topik sama.

- Keadaan yang terkait dengan
faktor-faktor yang $\begin{aligned} & \text { menyebabkan } \\ & \text { pemanfaatan }\end{aligned}$ suatu teks memiliki
ketergantungan terhadap pengetahuan
mengenai satu teks yang dijumpai terdahulu
atau sesudahnya (Beaugrande, 1981:183).

Serangkaian kalimat terkait baik dalam wujud ataupun maknanya dengan serangkaian kalimat yang lain (Rankema, 1993:37).

Intertekstual tidak hanya terjadi dalam dialog dimana seorang pembicara harus menyimak tanggapan verbal lawan bicaranya sehingga keterkaitan kalimat dapat dipertahankan. Intekstual juga dapat terjadi dalam monolog dimana pembicara atau penulis tidak perlu memperhatikan tanggapan verbal lawan bicara atau pembacanya.

Untuk suatu monolog manusia memperhatikan paling tidak empat unsur (Clark dan Clark 1977 : 232 dalam Dardjowidjojo 1986 : 94). Pertama, ia harus mengetahui masalah yang ingin ia nyatakan atau gambarkan. Kedua, dari masalah - yang sebenarnya merupakan proposisi global- ini, ia harus memilih sub-proposisi- subproposisi yang mana yang layak dikemukakan sehingga ia tidak akan memberikan informasi lebih atau kurang dari yang diperlukan. Ketiga, ia harus menentukan urutan penyajian sub-proposissub-proposisi ini sedemikian rupa sehingga pembaca atau pendengar dapat mengikuti arus pikirannya dengan mudah. Dan keempat, ia harus dapat menghubungkan sub-proposis- sub-proposisi ini sehingga terbentuklah kelompok-kelompok proposisi yang serasi.

Dengan demikian jelaslah bahwa suatu rentetan kalimat barulah dapat membentuk suatu pengertian, apabila kaliamat-kalimat tadi serasi dan terpadu. Kalau kita meminjam istilah Longacre (1983), perpaduan ini menyangkut dua lokus. Pertama dalam "notion deep structure" haruslah terdapat keserasian antara satu nosi di satu kalimat dan nosi di kalimat yang lain. 
Kedua, perpaduan dan pertalian nosi-nosi ini harus mempunyai manifestasi fonetis pada struktur lahir (surface structure). Keberterimaan suatu wacana ditentukan oleh ada tidaknya hubungan yang serasi di antara kedua macam struktur ini.

Bisa disimpulkan bahwa setiap kalimat atau teks tidak berdiri sendiri tetapi memiliki keterkaitan baik dalam wujud maupun maknanya dengan kalimat yang lain atau teks yang lain.

Intertekstualiatas adalah hubungan makna atau bentuk antara serangkaian kalimat, klausa, atau kata dengan serangkain kalimat, klausa, atau kata lain.

\subsection{Jenis Intertekstualitas}

Menurut Beaugrande/Dressler (1981) dalam Heinz 1994:58) ada dua jenis intertekstualitas yaitu:

a. Intratekstualitas (als Bezug auf die texstore)

Intratekstualitas adalah hubungan makna atau bentuk antara serangkaian kalimat, klausa, atau kata dengan kalimat, klausa, atau kata lain yag terdapat dalam teks yang sama. Umumnya, terdapat dalam puisi dengan pengulangan kata di beberapa bait dan juga pada surat kanbar dengan adanya pengulangan kata di tiap paragraf.

b. Ekstratekstualitas (als Bezug auf andere Texte)

c. Ekstratekstualitas adalah hubungan makna atau bentuk antara serangkain kalimat, klausa, atau kata dengan kalimat, klausa, atau kata dlam teks lain. Ekstratualistualitas dapat diwujudkan dalam pengulangan nama tokoh, hal, atau peristiwa dari satu teks ke dalam teks yang lain.

Intertekstualitas suatu teks berkaitan dengan kohesi dan koherensi teks tersebut. Kohesi dan koherensi merupakan salah satu alat untuk menentukan intertekstualitas sebuah teks.

\subsection{Kohesi dan Koherensi}

\section{A. Kohesi}

Menurut Heinz (1994:35-36) ada tiga jenis kohesi. Ketiga jenis kohesi tersebut adalah berikut.

a. Substitusi

Substitusi merupakan bentuk pengulangan suatu bagian teks yang memiliki keterkaitan makna dengan suatu bagian teks lain yang tertulis sebelumnya. Contoh:

Paul ist mit Flocki zum Tierarzt gegangen. Er hat ihm eine Spritze gegeben.

Dalam contoh di atas, er merupakan substitusi untuk Tierarzt (dokter hewan). Oleh karena itu yang biasanya memberikan suntikan (eine Spritze) adalah dokter, er tidak mungkin mengacu pada Paul. Substitusi tidak hanya berupa pronomina persona (er, sie), melainkan juga pronomina demonstrativa es, das, dies (-e,-es,em), dan artikel ein (-e, -er,-em,-en). Selain itu, substitusi dapat berupa sinonim, hiponim, hipernim, dan juga metafor. Contoh:

- Auf dem Markt heute morgen gab es ganze Stande voll mit verschiedenfarbigen Petunien. Diese Balkonpflanzen sind fur mich einfach die allerschonsten.

- Das Gold wurde von einem Drachen bewacht. Der Lindwurm totete jeden, der den Schatz erobern wollte.

Petunien-Balkonplanzen merupakan contoh bentuk substitusi yang menggunakan hubungan sinonim dari ketiga kata tersebut yang sama-sama mempunyai arti 'naga'.

b. Elipsis

Elipsis adalah penghilangan suatu bagian kalimat tanpa mengubah makna kalimat. Fungsi elipsis adalah untuk memadatkan kalimat.

Contoh:

"Ich liebe dich!-"Ich dich auch!" 
Dalam contoh di atas, kata yang dielipsiskan adalah liebe.

c. Rekuren

Rekuren merupakan pengulangan salah satu elemen dari teks sebelumnya di teks berikutnya. Contoh:

Gestern habe ich einen Vogel beim Nestbau beobachten. Der Vogel war ganz klein, hat aber trotzdem ziemlich grosse Zweige angeschleppt. Als Nistplatz hatte sich der Vogel ausgerechnet die Nische uber unserem Rolladenladenkasten ausgesucht.

Dalam contoh di atas, kata yang diulang atau di-rekkurenz-kan adalah Vogel.

B. Koherensi

Menurut Heinz (1994: 42) koherensi disebut sebagai textbildender Zusammenhang von Satzen yaitu hubungan atau keterkaitan dari kalimat-kalimat yang membentuk satu teks. Menurut Bussmann koherensi merupakan perpaduan antara hubungan gramatikal (kohesi) dan hubungan makna antarkalimat dalam teks itu sehingga dapat membentuk kesatuan makna.

Selain itu, ada unsur lain yang juga berkaitan dengan koherensi, yaitu die Sinnkontituitat atau keberlangsungan makna. Die Sinnkontituitat atau keberlangsungan makna teks berarti melihat apakah teks tersebut mempunyai kesinambungan isi dari judul hingga kalimat terakhir dalam teks tersebut.

Beaugrande/Dressler dalam Heinz (1994: 43) menjelaskan dengan baik perbedaan Sinn dan Bedeutung. Beaugrande/Dressler mengatakan bahwa dengan Bedeutung (arti) kita dapat menunjukkan, menjelaskan, ataupun menggambarkan sesuatu berdasarkan apa yang ada di kepala kita yang kita dapatkan secara indrawi (virtuelle Bedeutung). Akan tetapi, dengan Sinn (makna), kita menunjukkan sebuah pemahaman terhadap sesuatu yang disampaikan melalui sebuah pernyataan. Menurut Beaugrande/Dressler, banyak pernyataan yang memiliki lebih dari satu kemungkinan arti, tetapi dalam penggunaannya dalam teks, satu pernyataan atau satu kata hanya mempunyai satu makna.

Dari pemaparan di atas, disimpulkan bahwa koherensi melihat hubungan makna antarkalimat dalam sebuah teks sebagai satu kesatuan makna. Kohesi atau hubungan gramatikal antarkalimat dapat membantu menemukan kekoherensian teks itu. Koherensi juga berkaitan dengan die Sinnkontituitat atau keberlangsungan makna dari semua unsur penyusun teks.

(1) Kahn kritisierte seinen Chef. Er wurde entlassen

(2) Es regnet. Gib mir den Hund!

Er pada kalimat Er wurde entlassen mengacu pada Khan. Verba pada kalimat tersebut adalah wurde entlassen. Entlassen berarti 'memecat'. Wurde merupakan verba bantu yang berfungsi membentuk verba pasif sehingga wurde entlassen berartu 'dipecat'. Dengan demikian, er pada kalimat Er wurde entlassen mengacu pada Kahn bukan pada seinen Chef, dengan presupposisi Kahn adalah pegawai, Kahn mengkritik pimpinannya (seinen Chef) sehingga Kahn dipecat. Berdasarkan analisis di atas, kalimat (1) merupakan kalimat yang koheren yang mempunyai hubungan sebabakibat.

Meskipun tidak ditemukan hubungan kohesi secara eksplisit, kalimat (2) juga merupakan kalimat yang koheren. Es regnet yang berarti 
'hujan' merupakan alasan mengapa penutur meminta mitra tuturnya menyerahkan anjing (itu). Presupposisi kalimat (2) adalah anjing itu akan sakit jika kehujanan. Dengan demikian, meskipun pada kalimat (2) tidak ada kata yang saling mengacu, kalimat (2) tetap koheren karena mempunyai hubungan makna sebab-akibat secara implisit.

Berdasarkan dua contoh di atas, terlihat bahwa untuk menemukan hubungan makna atau koherensi sebuah teks diperlukan proses interpretasi, terlebih jika tidak ditemukan hubungan kohesi secara eksplisit. Pentingnya proses interpretasi ini sejalan dengan penjelasan yang ada pada bab 1 mengenai bagan komunikasi. Dalam penjelasan bagan komunikasi, dituliskan bahwa untuk dapat menangkap pesan yang dikomunikasikan penulis kepada pembacanya melalui tulisan, perlu dilakukan proses interpretasi, yaitu usaha menemukan makna terdalam, baik dari sebuah pernyataan, kalimat, atau teks dan menjelaskannya. Agar interpretasi tidak terlalu melebar dan dapat mendekati makna yang sebenarnya, dalam berinterpretasi seseorang tetap harus memerhatikan keberlangsungan makna (die Sinnkontituitat) antarunsur penyusun teks tersebut.

\section{Proposisi}

Proposisi adalah makna dasar dari sebuah pernyataan. Untuk menentukan proposisi sebuah pernyataan atau kalimat yang perlu diperhatikan adalah verba dari pernyataan atau kalimat tersebut yang umumnya berfungsi sebagai predikat.

John finally bought a present for mother.

Verba dari contoh kalimat di atas adalah bought, bentuk lampau dari buy yang berarti 'membeli'. Untuk menentukan proposisi kalimat di atas, kala (dalam konteks ini bought yang menunjukkan bahwa kala kalimat di atas adalah lampau) ataupun verba modal tidak perlu diperhatikan. Dengan demikian, proposisi dari kalimat di atas adalah john membeli (sesuatu).

Berdasarkan contoh di atas, dapat disimpulkan bahwa hal utama dalam menentukan sebuah proposisi adalah predikat dan subjek pelaku suatu pernyataan atau ujaran. Selain itu, dapat disimpulkan pula bahwa proposisi merupakan makna dasar dari sebuah pernyataan.

D. Presuposisi

Ketika membaca sebuah teks, tidak semua kalimat atau pernyataan yang tertulis dapat langsung dipahami. Begitu halnya ketika pengguna teks mencoba menemukan hubungan semantik (koherensi) antara suatu pernyataan atau kalimat dengan pernyataan atau kalimat lain tanpa ditandai hubungan kohesi (lihat contoh kalimat (2) halaman 11). Hal tersebut mungkin terjadi karena adanya informasi implisit yang tersimpan di dalam pernyataan atau kalimat yang tertulis tersebut. Informasi tersebut sengaja diimplisitkan karena adanya anggapan di benak penulis teks bahwa pengguna teks sudah mengetahui informasi tersebut. Informasi implisit itulah yang disebut presuposisi.

Presuposisi suatu pernyataan atau kalimat dapat merupakan hal yang bertentangan dengan pernyataan atau kalimat tersebut, contoh: john is opening the window, presuposisi dari kalimat tersebut adalah the window is closed before.

Selain itu, presuposisi juga dapat dilihat dari salah satu kata dalam pernyataan atau kalimat dan juga struktur kalimatnya, contoh Carl 
has flu again. Presuposisi dari kalimat tersebut adalah Carl has had the flu before. Presuposisi tersebut muncul ditandai dengan adanya kata again yang menunjukkan pengulangan terhadap suatu hal yang pernah terjadi sebelumnya.

\subsection{Pengertian Surat Kabar}

Surat kabar bisa dikatakan sebagai media massa tertua sebelum ditemukan film, radio, dan televisi. Salah satu kelebihan surat kabar adalah mampu memberi informasi yang lebih lengkap, bisa dibawa ke mana-mana, terdokumentasi sehingga mudah diperoleh bila diperlukan.

Berbicara tentang surat kabar sebagai salah satu bentuk media massa, maka permasalahan itu senantiasa berhubungan dengan jurnalistik, secara fungsional jurnalistik memang tidak dapat dipisahkan dengan surat kabar atau pers, sehingga jurnalistik adalah bentuk komunikasinya, sedangkan pers adalah media dimana jurnal itu disalurkan.

Terbitan yang menitikberatkan pada penyampaian berita, yang sering disebut dengan harian, karena terbit tiap hari. Sebutan harian sebenarnya untuk membedakan dengan terbitan lain yang terbit tiap minggu, bulan dan lain sebagainya yang biasanya disebut majalah.

Sering pula disebut dengan koran karena dibuat dari jenis kertas koran. Surat kabar sebetulnya kata lain dari pers, tapi kemudian pengertiannya semakin luas. Kini televisi dan radio diklasifikasikan juga sebagai pers. Arti pers yang sebenarnya adalah menekankan huruf-huruf ke atas kertas yang hendak dicetak maka segala barang yang pernah "di press" itu lantas disebut pers (Palapah, 1983:101-102)

Dja'far Assegaf mendefinisikan surat kabar sebagai berikut,

"Penerbitan yang berupa lembaran yang berisi berita-berita, karangan-karangan dan iklan yang dicetak dan terbit secara tetap atau periodik dan dijual untuk umum" (Assegaf, 1991:140)

Pada awalnya surat kabar seringkali diidentikkan dengan pers namun kerena pengertian pers sudah luas, dimana media elektronik sekarang ini sudah dikategorikan dengan pers juga. Untuk itu pengertian pers dalam arti sempit dan luas, pers hanya meliputi media cetak saja, salah satunya surat kabar.

Surat kabar adalah lembaran tercetak yang memuat laporan yang terjadi di masyarakat dengan ciri-ciri terbit secara periodik, bersifat umum, isinya termasa dan aktual mengenai apa saja dan dari mana saja di seluruh dunia untuk diketahui pembaca (Effendy, 1993:241).

Mengenai ciri-ciri yang dikemukakan di atas, dalam bukunya Ilmu, Teori dan Filsafat Komunikasi, Onong Effendy menjelaskan bahwa yang dimaksud terbit secara periodik adalah adanya keteraturan terbitnya surat kabar bisa setiap hari, satu kali seminggu, dua kali seminggu, kemudian yang dimaksud dengan bersifat umum atau publisitas adalah isi surat kabar terdiri dari berbagai hal yang erat kaitannya dengan kepentingan umum. Selanjutnya untuk ciri yang menyebabkan isinya termasa atau aktual, diartikan bahwa surat kabar meneliti kecepatan dalam menyajikan laporan, tanpa mengesampingkan kebenaran berita. Sedangkan ciri terakhir yaitu mengenai apa saja dan bagaimana saja diseluruh dunia yang mengandung nilai untuk diketahui khalayak atau pembaca (universalitas), berarti menyangkut kesemestaan dan beraneka ragam.

\subsection{Pengertian Berita}

Berita merupakan inti dari suatu penerbitan surat kabar. Lebih dari $50 \%$ isi dari surat kabar adalah berita atau news yang dapat diketahui dalam penjelasan para ahli komunikasi.

Earl English dan Clarence Hach dalam bukunya "Scholastic Journalism" mengatakan pendapatnya dalam batasan berita, yakni 'news is difficult ti define, because it involves many variable factors'(Assegaff, 1983: 21)

Dari pendapat diatas dapat disimpulkan bahwa sangat sulit memberikan batasan berita karena berita mencakup banyak faktor. Namun menurut Assegaff, batasan dan 
pengertian berita serta nilai berita sangatlah penting bagi seorang wartawan. Pengertian akan berita dan kepandaian menilai berita dapat menentukan karir seorang wartawan.

Banyak ahli yang mencoba memberikan batasan tentang berita, beberapan batasan yang dapat dikemukakan antara lain, batasan berita menurut Dean M. Lyle Spencer dalam bukunya "News Writing", adalah; 'Berita dapat dibataskan sebagai suatu kenyataan atau ide yang benar yang dapat menarik perhatian sebagian besar pembaca' (Assegaff, 1983: 23)

Kemudian menurut Dr. Williard C. Bleyer dalam "Newspaper Writing and Editing" berpendapat bahwa "Berita adalah sesuatu yang termasa yang dipilih oleh wartawan untuk dimuat dalam surat kabar karena ia dapat menarik atau mempunyai makna bagi pembaca surat kabar atau karena ia dapat menarik pembaca-pembaca tersebut" (Assegaff, 1983: 24)

\section{Berita Utama}

Di dalam setiap penulisan berita tidak lengkap rasanya jika suatu berita itu tidak menarik perhatian khalayak banyak atau berita dari segala berita atau yang sering disebut juga dengan Berita utama. Pembaca pada umumnya ketika pertama kali melihat berita, maka yang dibacanya yaitu berita utama-nya, karena berita utama yang menarik adalah berita yang mampu menerangkan keseluruhan dari isi beritanya. Oleh karena itu pengertian dari Berita Utama itu sendiri menurut YS. Gunadi, dalam bukunya Himpunan Istilah Komunikasi, sebagai berikut:

1. Menolong pembaca agar cepat mengetahui kejadian yang diberitakan.

2. Untuk menonjolkan suatu berita dengan dukungan teknik grafika.

3. Judul harus mencerminkan isi berita secara keseluruhan, yang ditulis ringkas, merangsang, mudah dimengerti, dan tidak menggunakan bahasa klise, serta judul harus logis (Gunadi,1998:10)

Berita utama berisikan berita atau informasi penting yang harus segera diketahui oleh khalayak dan bersifat aktual dari berbagai bidang yang disajikan di setiap harinya pada surat kabar.

Menurut A. H. Hoeta Soehoet, berita utama adalah berita terpenting dari semua berita yang disajikan dalam surat kabar, oleh sebab itu disediakan tempat utama yang mudah dibaca, yaitu halaman pertama bagian paling atas sebelah kiri. (Soehoet,1987: 2-3)

\section{METODOLOGI}

Penelitian yang dilakukan ini merupakan penelitian kualitatif, dengan teknik analisis isi. Teknik analisis menurut Miles dan Hubermen dilakukan dengan menempuh model alir, yakni reduksi data, penyajian data, dan menarik kesimpulan/verifikasi (Mattew B. Miles dan A. Michael Huberman, 1992).

Metode yang digunakan dalam penelitian ini adalah metode analisis isi, yakni mengalisis isi berita-berita utama internasioanal pada surat kabar di Timur Tengah.

Data dan sumber data penelitian ini adalah berita-berita internasional pada surat kabar online di Timur Tengah yaitu Asharq Al-Awsat yang diterbitkan di Saudi Arabiah dan Al-Ahram yang diterbitkan di Mesir yang diakses pada tanggal 1 Juli 2014 - 10 Juli 2014 2014. Pemilihan waktu tersebut didasarkan pada isu Islamic State of Iraq and Syria (ISIS) yang diprokmasikan pada tanggal 29 Juli 20142014.

Sedangkan teknik analisis menurut Mayring merupakan cara yang digunakan untuk pemahaman pesan-pesan simbolik dari wacana atau teks, dalam penelitian ini adalah berita-berita utama internasioanal pada surat kabar As-Sharq Al-Awsat dan Al-Ahram.

Data berita-berita pada kedua surat kabar ini kemudian dianalisis dengan cara mengukur intertekstualitas berita utama internasional yang disajikan dari kedua surat kabar tersebut melalui alat ukur intertekstualitas yaitu kohesi yang mempunyai 3 jenis: substitusi, elipsis, dan Rekuren dan koherensi yang mempunyai 2 jenis yaitu proposisi dan presuposisi. 


\section{HASIL DAN PEMBAHASAN}

Setelah peneliti menganalisis teks-teks berita utama internasional yang digunakan dalam surat kabar Syarqil Awsat dan Ahram dengan kajian intekstualitas dapat disimpulkan bahwa tema yang diangkat di kedua media tersebut mengangkat isu Islamic State of Iraq and Syria(ISIS).

Teks-teks berita utama internasional pada kedua surat kabar tersebut yang menjadi sumber analisis penelitian ini adalah 20 berita utama, 10 dari Syarqil Awsat dan 10 Ahram yang diterbitkan pada 10 hari yang berbeda dari tanggal 1-10 Juli 20142014 . .

Untuk mengetahui intertekstualitas berita-berita utama internasional baik pada surat kabar Syarqil Awsat dan Ahram peneliti menyandarkan pada jenis intertekstualitas yaitu kohesi yang mempunyai 3 bagian yaitu: subtitusi, elipsis, Rekuren dan koherensi yang mempunyai 2 bagian yaitu: proposisi dan presuposisi.

Temuan penelitian menunjukkan bahwa berita-berita utama internasional pada surat kabar As-Syarqul Awsat dan surat kabar Al-Ahram memberitakan tentang Islamic State of Iraq and Syria (ISIS). Hal ini didasarkan pada seluruh teks berita utama internasional pada kedua surat kabar ini sebanyak 20 teks memberitakan tentang ISIS.

Intekstualitas dari jenis koherensi dari proposisi dan presuposisi sangat dominan karena ada pada seluruh teks yang berjumlah 18 teks. Sedangkan dari jenis kohesi didapatkan kohesi pada surat kabar Syarqul Awsat yaitu: subtitusi 3 teks, elipsis 2 teks, dan pada Rekuren 3 teks. Pada surat kabar Ahram tidak ditemukan subtitusi, elipsis, dan rekuren didapatkan 7 teks. Koherensi didapatkan pada surat kabar Syarqul Awsat proposisi 9 teks dan presuposisi 9 teks sedangkan pada surat kabar Ahram didapatkan proposisi 9 teks dan presuposisi 9 teks.

Berikut beberapa contoh kohesi dan kohensi dari berita-berita utama internasional pada kedua surat kabar tersebut yang ditemukan dalam penelitian. Pada surat kabar As-Syarqul Awsat sebagai berikut:

Teks berita tanggal 1 Juli 2014

$$
\text { والعشب ينسحب من بلدة بالغوطة.. }
$$

«ISIS» merebut kota Balgoth.. ditemukan tujuh mayat di markasnya dan puluhan orang terbunuh dan terluka tembak sehingga memperluas daerah kekuasaan ISIS di kota Idleb"

2014

Teks berita tanggal 2 Juli

$$
\text { خلافة البغدادي«..ومعانيها السياسية }
$$

"Khilafah Bagdadi dan makna politiknya"

Pada berita tanggal 1 Juli terdapat kata داعش" ISIS" sedangkan pada berita pada tanggal 2 Juli didapatkan خلافة البغدادي "Khilafah Baghdadi”. Secara kohesi tidak didapatkan subtitusi, elipsis dan rekuren pada kedua teks berita ini. Namun pada sisi koherensi, dapat ditemukan keterkaitan pada kedua berita tersebut baik dari bentuk proposisi dan presuposisinya. Pada teks pertama kata داعش" ISIS" dan teks kedua خلافة البغدادي "Khilafah Baghdadi” dapat dipahami secara langsung bahwa seperti di ketahui ISIS di bawah pimpinan Abu Bakar Baghdadi dan pada teks kedua خلافة البغدادي terdapat bagian teks Khilafah Baghdadi yang dimaksudkan adalah ISIS . Pada kedua teks berita ini terdapat berkaitan pada tema ISIS. Sedangkan pernyataan sebaliknya dapat dipahami

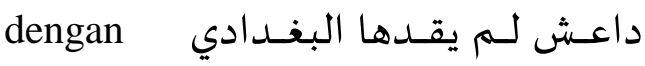
Bahwa ISIS tidak di bawah pimpinan Baghdadi sebelumnya.

Teks berita tanggal 2 Juli 
خلافة البغدادي".. ومعانيها السياسية

"Khilafah Bagdadi dan makna politiknya"

Teks berita tanggal 3 Juli 2014

$$
\text { أرسلوهم إلى دولة البغدادي }
$$

"Kirimkanlah mereka ke Negara Baghdadi"

Pada berita tanggal 2 Juli terdapat

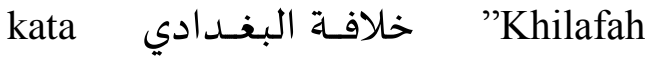
Baghdadi”. Sedangkan pada berita pada tanggal 3 Juli didapatkan دولة "negara Baghdadi" .Secara kohesi tidak didapatkan subtitusi dan rekuren pada teks tersebut, sedangkan elipsis kata "البغـادي" terdapat pengurangan yang seharusnya أبـو بكر البغــادي yaitu Abu Bakar Baghdadi pemimpin ISIS, pengurangan nama aslinya tidak mengurangi makna yang disampaikan oleh teks dan ini merupakan bagian dari elipsis..

2014

Teks berita tanggal 5 Juli

Peng-ISIS-an dan meng- ISIS-kan

2014

Teks berita tanggal 6 Juli

Akankan muncul" ISIS-ISIS" baru?

Pada berita tanggal 5 Juli terdapat kata geng-ISIS-an dan meng- ISIS-kan, sedangkan pada berita pada tanggal 6 Juli didapatkan دواعشُ "ISIS-ISIS" .Secara kohesi didapatkan subtitusi yaitu pada teks kedua دواعش " "ISIS-ISIS" menunjukan pengulangan bagian yang merujuk kepada pada teks pertama التـدعيش والدعشنـة pengISIS-an dan meng- ISIS-kan , namun elipsis dan rekuren tidak didapatkan pada kedua teks berita ini.

Contoh pada surat kabar $\mathrm{Al}$ Ahram sebagai berikut:

Teks berita tanggal 1 Juli 2014

$$
\text { حلو (داعش) قبل حساء الأنظمة }
$$

"Manisnya ISIS sebelum sajian sup siap dihidangkan"

Teks berita tanggal 2 Juli 2014

$$
\text { خلافة 》داعش" وهم سيتبدد بسرعة }
$$

"Khilafah ISIS angan-angan yang akan tercerai-berai dengan cepat"

Pada berita tanggal 1 Juli dan tanggal 2 Juli terdapat kata دواعش " ISIS". Secara kohesi tidak didapatkan subtitusi dan elipsis tetapi didapatkan rekuren yaitu pengulangan bagian teks داعش " ISIS" pada kedua teks tersebut.

Pada sisi koherensi, dapat ditemukan keterkaitan pada kedua berita tersebut baik dari bentuk proposisi dan presuposisinya. Pada teks pertama menyebutkan داعش" ISIS" baru dan teks kedua diulangi kata " ISIS" dengan menyatakan pemimpin ISIS adalah orang yang paling bersalah di antara anggotanya dan dapat dipahami secara langsung bahwa ISIS adalah organisasi baru yang berpotensi berkembang meskipun dasar pembentukannya salah. Pada kedua teks berita ini terdapat berkaitan pada tema ISIS. Sedangkan pernyataan sebaliknya dapat dipahami dengan bahwa ISIS bukan organisasi bersatu.

\section{SIMPULAN}

Berdasarkan hasil analisis dapat disimpulkan bahwa berita-berita utama internasional pada surat kabar al-Syarqul Awsat dan surat kabar AlAhram memiliki topik yang sama 
yaitu berita seputar Islamic State of Iraq and Syria (ISIS)

Berita-berita utama internasional yang diambil dari surat kabar alSyarqul Awsat dan surat kabar AlAhram dari tanggal 1 sampai 10 Juli 2014 sebanyak 20 teks.

Berita-berita utama internasional pada surat kabar Syarqul Awsat yang diterbitkan dari tanggal 1 Juli sampai dengan 10 Juli memiliki keterkaitan tema tentang ISIS. Demikian juga halnya pada surat kabar Al-Ahram yang diterbitkan dari tanggal 1 Juli sampai dengan 10 Juli juga memiliki keterkaitan tema tentang ISIS.

Intertekstualitas pada kedua surat kabar ini diukur dengan kohesi yang memiliki 3 bagian substitusi, ellipsis, dan Rekuren dan koherensi yang memiliki 2 bagian yaitu proposisi dan presuposisi.

Didapatkan dari temuan penelitian bahwa keterkaitan berita-berita utama internasional dari surat kabar AsSyarqul Awsat dan surat kabar Ahram pada tema ISIS.

Kohesi didapatkan pada surat kabar Syarqul Awsat yaitu: subtitusi 3 teks, elipsis 2 teks, dan pada Rekuren 3 teks. Sedangkan pada surat kabar Ahram tidak ditemukan subtitusi, elipsis juga tidak ditemukan, dan pada Rekuren didapatkan 7 teks. Dari segi koherensi di hari yang berbeda didapatkan pada surat kabar Syarqul Awsat proposisi 9 teks dan presuposisi 9 teks. Demikian juga pada surat kabar Ahram didapatkan proposisi 9 teks dan presuposisi 9 teks.

\section{DAFTAR PUSTAKA}

Assegaf, Dja'far. Jurnalistik Masa Kini. Bandung: PT Remaja Rosda Karya,1991.

Beaugrande, Robert Alain de dan Wolfgang Ulrich Dressler. Introduction to Text Linguistics. London: Longman, 1981.

Dardjowidjojo, Soenjono. Benang Pengikat dalam Wacana. Pusparagam PT. Citra Aditya Bakti. 1993

Genette, G. (1997a) Palimpsests: Literature in the Second Degree. Channa Newman and Claude Doubinsky (trans.). Lincoln, NB: University of Nebraska Press.

Kristeva, J. Desire in Language: A Semiotic Approach to Literature and Art, trans. By Gora, T., Jardine, A. \& Roudiez, L. S. New York, NY: Columbia University Press. 1980

Linguistik dan Pengajaran Bahasa, ed. Bambang Kaswanti. Jakarta: Arcan. 1986

Mattew B.Miles dan A. Michael Huberman, Analisis Data Kualitatif, Terj. Tjetjep Rehendi Rihidi, Jakarta: UI Press, 1992

Palapah, M.O. dan Atang Syamsudin. Studi Ilmu Komunikasi. Bandung : Fakultas Ilmu Komunikasi Universitas Padjadjaran. 1983

Rankema, Jan. Discourse Studies: An Introductory Textbook. Amsterdam: John Benjamins Publishing Company. 1993.

Soehoet, A.M Hoeta. Teori Komunikasi. Jakarta: IISIP. 2002

http://www.aawsat.com

http://www.ahram.org.eg 